\title{
Does relatively lower water temperature create an opportunity to increase the stocking density in commercial production conditions of rainbow trout (Oncorhynchus mykiss, L., 1758)?
}

\author{
Ozgur Altan ${ }^{1 *}$, Hulya Saygi ${ }^{1}$ \\ ${ }^{1}$ Aegean University Faculty of Fisheries, Department of Aquaculture, 35100 Bornova- Izmir, Turkey \\ *Corresponding Author: Ozgur Altan, Aegean University Faculty of Fisheries, Department of \\ Aquaculture, 35100 Bornova- Izmir, Turkey
}

\begin{abstract}
In commercial production conditions, rainbow trout fry that average live weight is $1.3 \pm 0.2 \mathrm{~g}$ were placed in rectangular concrete ponds of 44 cubic meters with 15, 20, 40 and $60 \mathrm{fish} / \mathrm{m}^{3}$ stocking density, respectively, and fed for 270 days at an average water temperature of $8.3^{\circ} \mathrm{C}$ between June and February during which the growth and feed conversion ratios of fish were determined. At the end of the study, the best results were achieved with the stocking density of $15 \mathrm{fish} / \mathrm{m}^{3}$, and this was followed by the stocking density of $20 \mathrm{fish} / \mathrm{m}^{3}$. Stocking densities of 40 and $60 \mathrm{fish} / \mathrm{m}^{3}$ have shown lowest results and there has been no statistically significant difference between these two groups. When evaluating the feed conversion rate and specific growth rate of fish, no significant difference was observed between the experimental groups. The study concluded that low water temperatures has no positive effect on stocking density in commercial rainbow trout production.
\end{abstract}

Keywords: Rainbow trout, Oncorhynchus mykiss, low water temperature, stocking density, commercial production.

\section{INTRODUCTION}

Rainbow trout (Oncorhynchus mykiss, L., 1758) is one of the most leading and economically important species for inland water fish farming. The main reasons for this success can be attributed to the fish resistance to stress conditions, easy adaptation to commercial feeds, rapid growth at suitable temperatures, and the completion of aquaculture farming period with low feed conversion rates depending on the quality of the feed. Rainbow trout is also described as a cold water species. It is incubated at $10^{\circ} \mathrm{C}$ and grown at $12-16^{\circ} \mathrm{C} .[1,2,3]$.

Aquaculture is known for its primary aim to achieve profitable production through highest possible yield per unit of area. Therefore, the studies undertaken so far have examined different stocking densities and growth rates of fish. Important part of these studies is that $10-15 \mathrm{~kg} / \mathrm{m}^{3}$ stocking rates are identified as optimum, while stocking at $20 \mathrm{~kg}$ and higher is called "intensive" stocking densities $[4,5,6,7]$.

One of the most effective and simple ways to improve the operational efficiency in a rainbow trout farm with limited area is to increase the stocking density per unit of area as much as possible. However, the density in ponds can only be increased to a certain level unless there is a physical intervention such as external oxygenation support or oxygen generator [8,9]. Observations show that higher stocking density exposes fish to negative stress, decreases feeding efficiency, generates lesions on tails, dorsal fins and skin of the fish, particularly at high stocking rates spreads disease in aquaculture environment, and finally leads to fish deaths $[10,11,12]$. In order to protect the rainbow trout from these negative effects and to maintain an aquaculture model considering fish welfare, it has become obligatory in recent years to determine the optimum aquaculture farming criteria for each fish farm. The term of fish welfare, though being still discussed, can be described as the physical and mental harmony of fish with its environment. This better harmony can provide an improved growth rate; but it does not always mean the positive effects ranging from operational production costs to the taste of fish $[13,14,15]$. 
Does relatively lower water temperature create an opportunity to increase the stocking density in commercial production conditions of rainbow trout (Oncorhynchus mykiss, L., 1758)?

One of the primary factors causing to the slightly decreased operational efficiency is the low level of annual change in water temperature as in most of the trout farms that traditionally use spring rain water in concrete ponds. A fish farm that has been producing trout according to above-mentioned optimum water temperatures, can produce table fish size trout (average $250 \mathrm{~g}$ live weight) three times in two years, whereas a fish farm that has been producing trout lower than optimum temperatures, can produce maximum two times in two years. As expected, a trout farm that have been producing at lower temperatures becomes less competitive when compared to a trout farm that has been producing at average values.

As it is known, there is an inverse proportion between the water temperature and the dissolved oxygen of water [16]. One of the main issues that can be addressed is to increase the stocking density under low water temperature and high dissolved oxygen values in order to increase the productivity in such fish farms and accordingly forcing the competition limits against the enterprises producing at optimum density.

To serve the above purpose, the study has selected a commercial fish farm that has been producing rainbow trout at $5.7-11.1^{\circ} \mathrm{C}$ from June to February and compared the growth and feed conversion ratio data obtained at natural dissolved oxygen values under 20, 40 and $60 \mathrm{fish} / \mathrm{m}^{3}$, respectively, with the obtained results under commercial production capacity of $15 \mathrm{fish} / \mathrm{m} 3$ that is the control group of the study.

\section{Materials AND Methods}

The study was conducted for 270 days, from June to February, at a private trout farm where was located in Samsun-Turkey. A total of 18000 rainbow trout fry from the same batch in the hatchery where was located in the Black Sea region of Turkey, with an average live weight of $1.3 \pm 0.20 \mathrm{~g}$, were used in the trial. The fish was stocked at a rate of 20,40 and $60 \mathrm{fish} / \mathrm{m}^{3}$ at random to compare with a stocking rate of $15 \mathrm{fish} / \mathrm{m}^{3}$ as three replicates in the 44 cubic meters concrete ponds of the trout farm. The number of the fish in the experimental groups has been selected specifically that if the market size of the fish is accepted as $250 \mathrm{~g}$, the numbers also will serve as $15,20,40$ and $60 \mathrm{~kg} / \mathrm{m}^{3}$ in terms of the final product. The fish were not fed during the first two days to get rid of the transportation stress. All fish subject to the trial were fed ad libitum with commercial feed of a private producer, five times a day until $50 \mathrm{~g}$, and later on three times until the end of the experiment. The amount of feed given to fish was recorded daily. The nutritional composition of the feed used in the experiment are presented in Table 1 and Table 2. The water temperature, dissolved oxygen and $\mathrm{pH}$ values in the experimental ponds were measured with the YSI Professional plus Water Quality Instrument.

Table 1. Nutritional Composition of the Feed Used for Fry and Juvenile Trout (1.3-50 g)*

\begin{tabular}{|c|c|}
\hline Nutritional Content & Average value (\%) \\
\hline Crude protein & 52 \\
\hline Crude oil & 14 \\
\hline Crude cellulose & 1.4 \\
\hline Moisture & 12 \\
\hline Ash & 12 \\
\hline
\end{tabular}

* The values in the table were provided by the feed factory.

Table2. Nutrient composition of the feed used for adult trout (50-150 g)*

\begin{tabular}{|c|c|}
\hline Nutritional Content & Average value (\%) \\
\hline Crude protein & 46 \\
\hline Crude oil & 19 \\
\hline Crude cellulose & 2.5 \\
\hline Moisture & 12 \\
\hline Ash & 12 \\
\hline
\end{tabular}

* The values in the table were provided by the feed factory.

In order to determine the monthly average live weights of the fish and to calculate the feed conversion ratio (FCR), 50 fish were randomly taken from experimental ponds, fainted with an anesthetic agent 
Does relatively lower water temperature create an opportunity to increase the stocking density in commercial production conditions of rainbow trout (Oncorhynchus mykiss, L., 1758)?

named phenoxy ethanol, and then their live weights were measured with a sensitive scale of $0.001 \mathrm{~g}$. The following formulas were used to calculate the feed conversion ratio and specific growth rates:

Feed Conversion Ratio $(\mathrm{FCR})=$ Given feed $(\mathrm{g}) /$ Gained average live weight $(\mathrm{g})$

Specific Growth Rate (SGR) $=\ln$ (Final weight-g) $-\ln$ (Initial weight-g) x100) / t (in days)

\subsection{Statistical Evaluation}

The data set was submitted to the analyses of variance (ANOVA) with 95\% of confidence after the verification of the assumptions for Normality of the data using a Kolmogorov-Smirnov test and homogeneity of variance was also using the Levene test. Once these requirements were fulfilled, the mean values were approached the average comparisons using the Student-Newman Keuls test. In the case of non-parametric data, a Kruskal-Wallis $\mathrm{H}$ test was performed. All the statistical analysis was conducted using Statistical Package for Social Science (SPSS for Windows; v19.0, USA) and differences were considered statistically significant when $P<0.05$.

\section{RES ULTS AND Dis CUSSION}

\subsection{Change of Water Quality Values in Ponds}

The mean water temperature was determined as $8.37 \pm 2.17^{\circ} \mathrm{C}$ during the 270 -day experiment, the warmest month average was measured at $11.1^{\circ} \mathrm{C}$ in July, and the coldest month average at $5.7^{\circ} \mathrm{C}$ in December. Dissolved oxygen level was detected as $8.3 \pm 0.57 \mathrm{mg} / \mathrm{L}$ in all experimental ponds, and $\mathrm{pH}$ as $7.56 \pm 0.21$. The weekly $\mathrm{NO}_{3}, \mathrm{NO}_{2}, \mathrm{NH}_{3} / \mathrm{NH}_{4}$ values attained did not exceed the reliable values. According to the obtained data the survival rate for all groups were more than $90 \%$ and there was no statistically significant difference between the experimental groups $(P \geq 0.05)$

\subsection{Change of the Rates in Growth, Development and Feed Consumption by Fish}

During the assessments, fish in all groups farmed under water temperature decreasing up to $8.3^{\circ} \mathrm{C}$ between June and October with the commercial juvenile feed, whose nutritional content is given in Table 1, showed similar growth and development rates, and there was no significant difference in live weight development of fish in experimental groups $(P \geq 0.05)$. However, with the water temperature falling to $8^{\circ} \mathrm{C}$ and below and use of commercial feed with the nutrient content given in Table 2 made significant differences. Although the stocking density of $15 \mathrm{fish} / \mathrm{m}^{3}$ identified as the control group showed the best live weight growth and insignificant difference when compared to the group with the stocking density of $20 \mathrm{fish} / \mathrm{m}^{3}$ there was no significant differences between these two groups $(P \geq 0.05)$. On the other hand, the average live weight of fish farmed under both stocking densities showed a higher increase rate than the experimental groups of 40 and $60 \mathrm{fish} / \mathrm{m}^{3}$, the difference between them was found to be statistically significant $(P \leq 0.05)$. Finally, there was no statistically significant difference between the stocking densities of 40 and $60 \mathrm{fish} / \mathrm{m}^{3}(P \geq 0.05)$ (Table 3 and Figure 1).

Table3. Live Weight Changes of the experimental groups.

\begin{tabular}{|c|c|c|c|c|}
\hline Months & Stocking Density & $\overline{\boldsymbol{X}} \pm \boldsymbol{s}_{\overline{\boldsymbol{X}}}$ & $\mathbf{F}$ & $\mathbf{p}$ \\
\hline June & 15 & $1.30 \pm 0.20^{\mathrm{a}}$ & 0.158 & 0.925 \\
\hline & 20 & $1.30 \pm 0.20^{\mathrm{a}}$ & & \\
\hline & 40 & $1.30 \pm 0.20^{\mathrm{a}}$ & & \\
\hline & 60 & $1.30 \pm 0.20^{\mathrm{a}}$ & & 0.865 \\
\hline July & 15 & $4.01 \pm 3.19^{\mathrm{a}}$ & 0.244 & \\
\hline & 20 & $4.38 \pm 3.40^{\mathrm{a}}$ & & 0.211 \\
\hline & 40 & $4.50 \pm 3.47^{\mathrm{a}}$ & & \\
\hline August & 60 & $4.00 \pm 3.18^{\mathrm{a}}$ & & \\
\hline & 15 & $8.90 \pm 5.82^{\mathrm{a}}$ & & \\
\hline & 20 & $11.45 \pm 7.06^{\mathrm{a}}$ & & 0.062 \\
\hline September & 40 & $10.08 \pm 6.40^{\mathrm{a}}$ & & \\
\hline & 60 & $8.33 \pm 5.53^{\mathrm{a}}$ & & \\
\hline
\end{tabular}

International Journal of Innovative Studies in Aquatic Biology and Fisheries (IJISABF) 
Does relatively lower water temperature create an opportunity to increase the stocking density in commercial production conditions of rainbow trout (Oncorhynchus mykiss, L., 1758)?

\begin{tabular}{|c|c|c|c|c|}
\hline & 60 & $19.34 \pm 7.85^{\mathrm{a}}$ & & \\
\hline \multirow[t]{4}{*}{ October } & 15 & $46.60 \pm 13.40^{\mathrm{a}}$ & 2.557 & 0.059 \\
\hline & 20 & $41.15 \pm 12.37^{\mathrm{a}}$ & & \\
\hline & 40 & $39.25 \pm 12.00^{\mathrm{a}}$ & & \\
\hline & 60 & $33.86 \pm 10.91^{\mathrm{a}}$ & & \\
\hline \multirow[t]{4}{*}{ November } & 15 & $81.15 \pm 19.18^{a}$ & 5.147 & 0.003 \\
\hline & 20 & $71.90 \pm 17.73^{b}$ & & \\
\hline & 40 & $62.25 \pm 16.14^{\mathrm{c}}$ & & \\
\hline & 60 & $54.17 \pm 14.75^{\mathrm{c}}$ & & \\
\hline \multirow[t]{4}{*}{ December } & 15 & $97.50 \pm 21.46^{\mathrm{a}}$ & 15.226 & 0.000 \\
\hline & 20 & $86.85 \pm 19.89^{b}$ & & \\
\hline & 40 & $76.50 \pm 18.29^{b}$ & & \\
\hline & 60 & $67.77 \pm 16.89^{c}$ & & \\
\hline \multirow[t]{4}{*}{ January } & 15 & $113.20 \pm 23.70^{\mathrm{a}}$ & 13.464 & 0.000 \\
\hline & 20 & $100.80 \pm 21.96^{\mathrm{b}}$ & & \\
\hline & 40 & $88.80 \pm 20.20^{c}$ & & \\
\hline & 60 & $78.69 \pm 18.66^{c}$ & & \\
\hline \multirow[t]{4}{*}{ February } & 15 & $131.20 \pm 26.14^{\mathrm{a}}$ & 15.949 & 0.000 \\
\hline & 20 & $116.85 \pm 24.21^{\mathrm{b}}$ & & \\
\hline & 40 & $102.95 \pm 22.27^{\mathrm{c}}$ & & \\
\hline & 60 & $91.18 \pm 20.56^{\mathrm{c}}$ & & \\
\hline
\end{tabular}

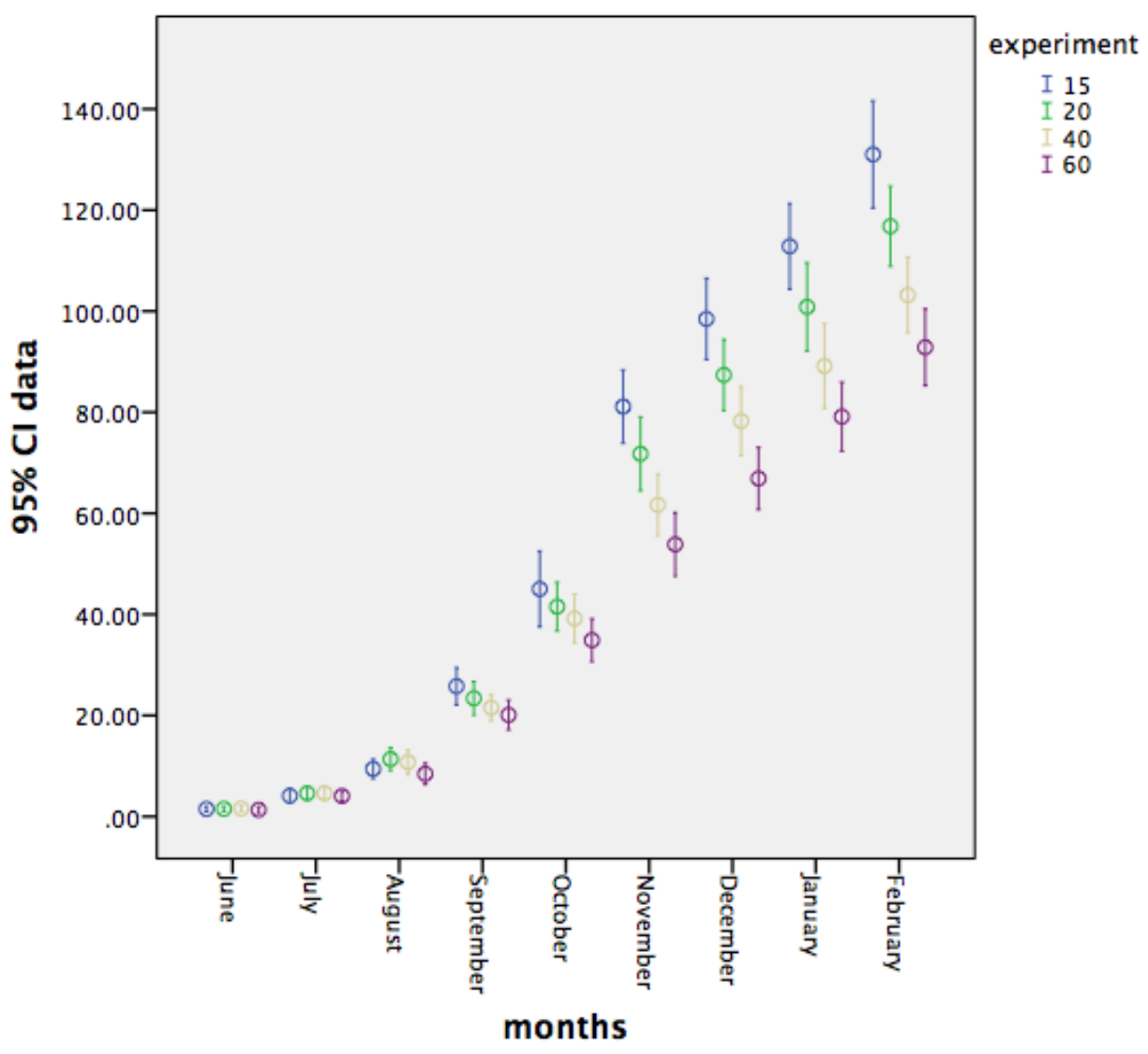

Figure1. Monthly Live Weight Changes of the Experimental Groups

The results of the study showed that trout fingerlings from the same batch provided better growth rate under stocking intensity of 15 and $20 \mathrm{fish} / \mathrm{m}^{3}$ in commercial aquaculture conditions when compared to the high stocking rates of 40 and $60 \mathrm{fish} / \mathrm{m}^{3}$. On the hand according to the obtained results with respect to the feed evaluation and specific growth rates of fish, it was determined that FCR of the experimental groups varied between 0.89 and 0.92 and SGR values ranged between 0.49 and 0.55 , and it was determined that there was no statistical difference between the experimental groups $(P \geq 0.05)$ (Figure 2). 


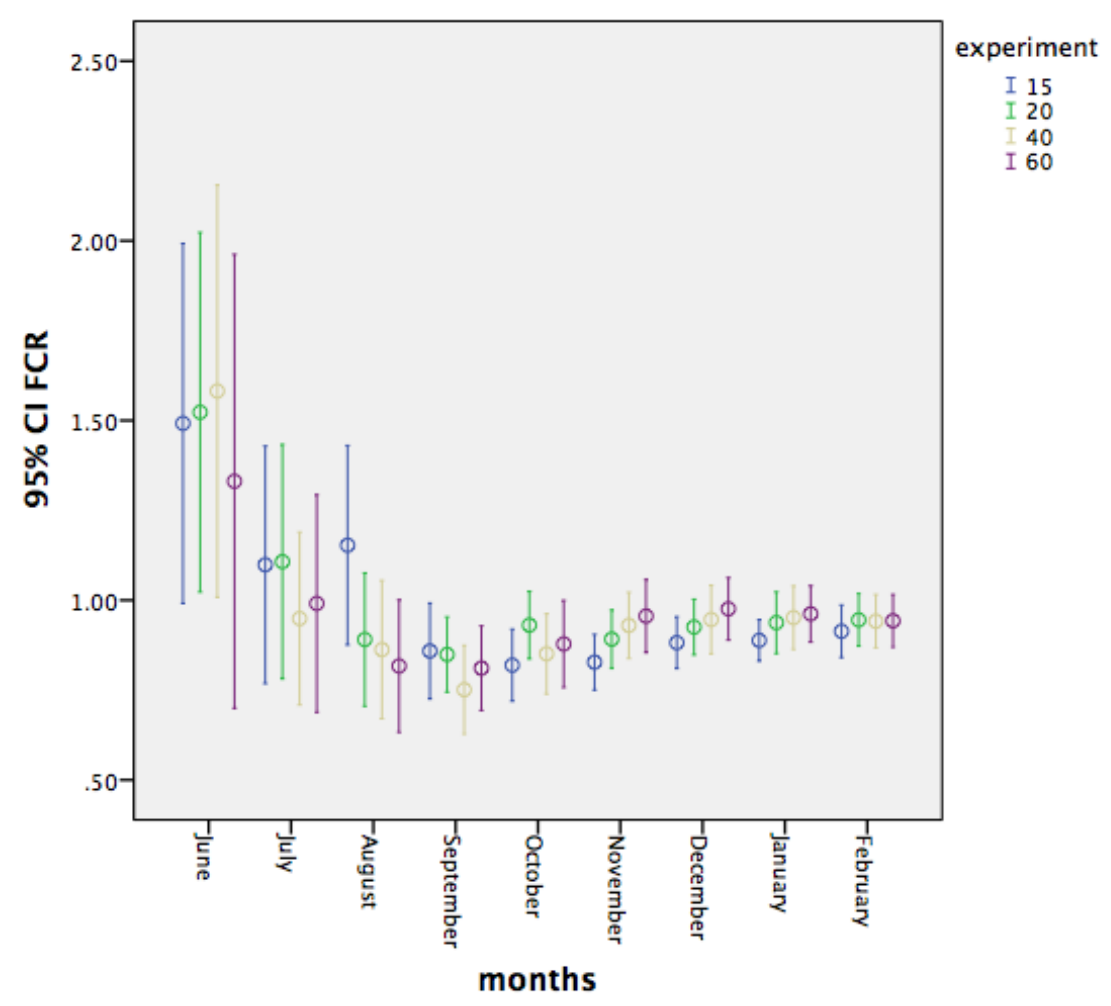

Figure2. Monthly FCR Changes of the Experimental Groups

The results of this study are of sectorial significance; because the experiment was carried out under fully commercial production conditions. The analysis of the previous stocking density studies of the rainbow trout shows that the experiments were mostly carried out in fully controlled PVC tanks. These studies mostly concluded that the stocking intensity were inversely proportional to growth and development data, and the feed evaluation and specific growth values heightened with the increasing stocking density $[17,4,18,19,20]$. Nevertheless, it was reported that the growth rate data in a stocking density as high as 40 and $80 \mathrm{~kg} / \mathrm{m}^{3}$ did not show any significant difference compared to lower stocking densities, however, such a high stocking density has been reported to cause deformation in tail fins $[8,21]$. The study has also revealed that the increase in stocking density of the rainbow trout leads to an increase in the value of stress indicators, which affects fish health and welfare $[5,22]$.

\section{CONCLUSiON}

Rainbow trout cultivated at low water temperature requires a longer farming period compared to the optimum water temperature farming model. The difference is extremely important from commercial perspective. However, this brings various problems for enterprises that have to produce at low temperatures and try to close the (profit) gap by producing more from a unit of area which particularly leads to the decrease in growth rate of fish. The study concludes that enterprises that have to produce at low water temperature can operate and have no problems in terms of growth development and feed consumption when the average stocking densities are increased up to $20 \mathrm{fish} / \mathrm{m}^{3}$.

\section{ACKNOWLEDGEMENT}

This study has been supported with the Project no 7130636 within the scope of the Turkish Scientific and Technological Research Council' Industrial Research and Development Program (TUBITAKTEYDEB). The authors thank to Ladik Akdag Trout Company Ltd. where the study was performed.

\section{REFERENCES}

[1] Abdulhai H. and Ghomi M., Rainbow trout culture in Iran: Development and concerns, Aquaculture Asia 10: 34 (2005).

[2] Craft C.D, Ross C., Sealey W.M., Gaylord T.G., Barrows F.T., Fornshell G. and Myrick, C.A., Growth, proximate composition, and sensory characteristics of Rainbow Trout Oncorhynchus mykiss consuming alternative proteins. Aquaculture 459: 223-231 (2016). 
Does relatively lower water temperature create an opportunity to increase the stocking density in commercial production conditions of rainbow trout (Oncorhynchus mykiss, L., 1758)?

[3] FAO, The State of World Fisheries and Aquaculture, Contributing to food security and nutrition for all, 200 pp, Rome (2016).

[4] Boujard T., Labbe L. and Auperin B., Feeding behavior, energy expenditure and growth of rainbow trout in relation to stocking density and food accessibility. Aquaculture Research 33: 1233-1242 (2002).

[5] Anras, M.L.B. and Lagardere, J.P., Domestication and behavior in fish. INRA Produccion Animale 17(3): 211-215 (2004).

[6] Conte F.S., Stress and the welfare of cultured fish. Appl. Animal Behavior Science 86: 205-223 (2004).

[7] Ashley P.J., Fish welfare: current issues in aquaculture. Appl. Animal Behavior Science 104: 199-235 (2007).

[8] Ellis T., North B., Scott A.P., Bromage N.R., Porter M. and Gadd D., The relationships between stocking density and welfare in farmed rainbow trout. Journal of Fish Biology 61: 493-531 (2002).

[9] Sindilariu P.D., Reduction in effluent nutrient loads from flow-through facilities for trout production: a review. Aquaculture Research 38: 1005-1036 (2007).

[10] Montero D., Izquierdo M., Tort L., Robaina L. and Vergara J., High stocking density produces crowding stress altering some physiological and biochemical parameters in gilthead seabream, Sparus aurata, juveniles, Fish Physiology and Biochemistry 20: 53-60 (1999).

[11] Håstein T., Animal welfare issues relating to aquaculture, in: OIE Global Conference on Animal Welfare, pp: 219-227 (2004).

[12] Tort L., Stress and immune modulation in fish, Development of Complete Immunolog y 35: 1366-1375 (2011).

[13] Appleby M.C. and Hughes B.O., Introduction. In: Appleby, M.C., Hughes, B.O. (Eds.), Animal Welfare, CABI, Oxfordshire, pp: xi-xiii (1997).

[14] Duncan I.J.H. and Fraser D., Understanding Animal Welfare. In: Appelby, M.C., Hughes, B.O. (Eds.), Animal Welfare, CABI, Oxfordshire, pp. 19-31 (1997).

[15] FSBI, Fish Welfare Briefing Paper 2. Fisheries Society of the British Is les (2002).

[16] Doudoroff P. and Shumway D., Dissolved Oxygen Requirements of Freshwater Fishes. FAO Fisheries Technical Paper no: 86. Rome (1970).

[17] Barton B.A. and Iwama G.K., Physiological changes in fish from stress in aquaculture with emphasis on the response and effects of corticosteroids. Annual Review of Fish Diseases 1:3-26 (1991).

[18] Larsen B.K., Skov P.V., McKenzie D.J. and Jokumsen A., The effects of stocking density and low level sustained exercise on the energetic efficiency of rainbow trout (Oncorhynchus mykiss) reared at $19^{\circ} \mathrm{C}$. Aquaculture 324-325: 226-233 (2012).

[19] McKenzie D.J., Höglund E., Dupont-Prinet A., Larsen B.K., Skov P.V., Pedersen P.B. and Jokumsen A., Effects of stocking density and sustained aerobic exercise on growth, energetics and welfare of rainbow trout. Aquaculture 338-341: 216-222 (2012).

[20] Laursen D.C., Larsen B.K., Skov P.V. and Höglund E., Improved growth performance in rainbow trout Oncorhynchus mykiss reared at high densities is linked to increased energy retention. Aquaculture 442: 69-73 (2015).

[21] North B.P. Turnbull J.F., Ellis T., Porter M.J., Migaud H., Bron J. and Bromage N.R., The impact of stocking density on the welfare of rainbow trout (Oncorhynchus mykiss). Aquaculture 255: 466-479 (2006).

[22] Yarahmadi P., Miandare H.K., Fayaz S., Marlowe C. and Caipang A., Increased stocking density causes changes in expression of selected stress - and immune-related genes, humoral innate immune parameters and stress responses of rainbow trout (Oncorhynchus mykiss). Fish \& Shellfish Immunology 48: 43-53 (2016).

Citation: O. Altan, H. Saygi,"Does relatively lower water temperature create an opportunity to increase the stocking density in commercial production conditions of rainbow trout (Oncorhynchus mykiss, L., 1758)? ", International Journal of Innovative Studies in Aquatic Biology and Fisheries, vol. 4, no.1, p. 26-31, 2018. http://dx.doi.org/10.20431/2454-7670.0401005

Copyright: (C) 2018 O. Altan, H. Saygi. This is an open-access article distributed under the terms of the Creative Commons Attribution License, which permits unrestricted use, distribution, and reproduction in any medium, provided the original author and source are credited. 